\title{
Difficulties of bachelor of nursing students in clinical practice - teacher's perspectives
}

\author{
Dificuldades dos estudantes do curso de licenciatura em enfermagem no ensino clínico - \\ perspectivas Docentes
}

João Longo

Escola Superior de Saúde Ribeiro Sanches - ERISA, Lisboa, Portugal

Email:joao.longo@erisa.pt

\begin{abstract}
This article focuses on representations of teachers about the difficulties perceived or felt by students in clinical training. This is the partial result of a study in construction process, carried out under the PhD in Educational Sciences in the area of Teacher Education. This research aims to understand the formative effect of the practice in the workplace in terms of knowledge acquisitions, development of professional knowledge and skills, and also in identity construction of teachers and students. This study is framed in the area of initial teacher education in nursing, more specifically in its practical component, and it is designed to answer the question: what are the main difficulties encountered by students in the workplace in initial nursing education? And the goal: to understand to what extent these difficulties can be constraints of learning and personal and professional development of the student. This is a study based on a qualitative approach of descriptive and interpretative nature.

The sample is intentional, consisting of sixty-eight teachers of thirteen Nursing / Health High Schools in Portugal. Data collection was carried out through focus group, and their examination was performed using the thematic content analysis according to Bardin[1]. The results show, according to the teaching perspective, that the difficulties experienced by students are polarized around six main categories: the reality shock; interact with the medical monitor; the self training process; interaction with the teacher; interaction with the patient / family, and also interaction with the nursing staff.
\end{abstract}

Keywords: Clinical Training in Nursing, Difficulties, Students

\section{Resumo}

Este artigo incide nas representações dos docentes sobre as dificuldades percebidas | sentidas pelos estudantes em ensino clínico. Trata-se do resultado parcial de um estudo em processo de construção, realizado no âmbito do Doutoramento em Ciências da Educação na área da Formação de Professores. Através desta pesquisa pretende-se compreender o efeito formativo da prática em contexto de trabalho no plano das aquisições, desenvolvimento de conhecimentos e competências profissionais e, ainda, na construção identitária docente e discente.

Enquadra-se na área da formação inicial em enfermagem, mais especificamente na sua componente prática, e tem como interesse responder à questão: quais as principais dificuldades sentidas pelos estudantes em contexto de trabalho na formação inicial em enfermagem? E ao objetivo: compreender em que medida essas dificuldades podem ser condicionantes das aprendizagens e do desenvolvimento pessoal e profissional do estudante. Trata-se de um estudo que assenta numa abordagem qualitativa de natureza interpretativa e descritiva e interpretativa.

A amostra é intencional, composta por sessenta e oito professores de treze Escolas Superiores de Enfermagem | Saúde de Portugal Continental. A recolha de dados foi efetuada através da técnica de focus group, e a análise dos mesmos foi executada com recurso à análise de conteúdo temática segundo Bardin[1]. Os resultados evidenciaram, segundo a perspetiva docente, que as dificuldades sentidas pelos estudantes se polarizam em torno de seis principais categorias: choque da realidade; interação com o supervisor clínico; o próprio processo formativo; interação com o professor; interação com o utente | família e, ainda, interação com a equipa de enfermagem.

Palavras-Chaves: Ensino Clínico em Enfermagem, Dificuldades, Estudantes. 


\section{Introduction}

The practice as a training device is unanimously accepted as a core in nursing education by the various stakeholders, and is considered a unique place and time in the development of cognitive, instrumental, relational and critical-reflective skills ${ }^{[2,3,4,5,6,7,8,9,10,11]}$.

Despite the discursive unanimity on the importance and centrality of the practice in the initial nursing education, several studies show weaknesses, contradictions and ambiguities of this component. Contexts, actors and processes ${ }^{[13]}$ can constitute real obstacles to student learning and the process of "becoming a nurse" itself. The most common examples of the dysfunctions identified relate to the persistent dichotomy between theory and practice ${ }^{[2,3,4,6,7,9,13,14,15]}$; lack of knowledge about how the students socialize and build their professional iden-

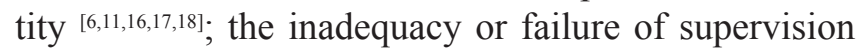
related to unpreparedness of supervisors and teachers for supervisor function, [2,19,20,21,22,23,24,25,26] and also the weak alignment between college and contextual work in the absence of effective partnerships ${ }^{[9,27,28,29,30]}$.

Thus, by showing the lack of consistency and coordination between the practical purposes of the initial training of nurses and the specific conditions under which this occurs, it is pertinent to increase knowledge about the difficulties perceived / felt by students in clinical training, even though "read through the eyes of teachers".

\section{Material and Methods}

Since we wanted to understand, from the perspective of teachers, to what extent the difficulties perceived / felt by students in clinical training can condition their learning personal and professional development, we focused on the qualitative approach of descriptive and interpretative nature.

Data collection was performed by applying the focus group technique ${ }^{[34,35,36]}$ to sixty-eight teachers of thirteen Nursing / Health High Schools of Portugal, with responsibilities at different levels of the theoretical or practical educational process.

A thematic matrix was defined, including the interaction between the emerging elements of the narratives of the subjects and themes identified in the literature. Subsequently, we performed the decontextualization of the analysis units compared to the initial dialogues, fol-

\section{Introdução}

A prática enquanto dispositivo de formação é unanimemente aceite como core da formação em enfermagem pelos diversos stakeholders, constituindo um lugar e um tempo ímpares no desenvolvimento de competências cognitivas, instrumentais, relacionais e crítico-reflexivas $[2,3,4,5,6,7,7,9,9,10,11]$.

Apesar da unanimidade discursiva relativamente à importância e centralidade da prática na formação inicial em enfermagem, diversos estudos evidenciam fragilidades, contradições e ambiguidades desta componente. Contextos, atores e processos ${ }^{[13]}$, podem constituir verdadeiros obstáculos à aprendizagem do estudante e ao próprio processo de "tornar-se enfermeiro". Os exemplos mais comuns das disfuncionalidades apontadas prendem-se com a persistência da dicotomia entre teoria e prática ${ }^{[2,3,4,6,7,9,13,14,15]}$; o desconhecimento sobre o modo como o estudante socializa e constrói a sua identidade profissional [6,11,16,17,18]; a inadequação ou insuficiência da supervisão relacionada com impreparação dos supervisores e docentes para a função supervisiva $[2,19,20,21,22,23,24,25,26]$ e, ainda, a fraca sintonia entre a academia e os contextos de trabalho, face à ausência de parcerias efetivas $[9,27,28,29,30]$.

Assim, ao evidenciar-se a falta de congruência e articulação entre os propósitos da prática na formação inicial de enfermeiros e as condições concretas em que a esta ocorre, torna-se pertinente aumentar o conhecimento sobre as dificuldades percebidas $\mid$ sentidas pelos estudantes em ensino clínico, ainda que "lidas pelos olhos dos professores".

\section{Material e Métodos}

Uma vez que pretendíamos compreender, na perspetiva dos docentes, em que medida as dificuldades percebidas $\mid$ sentidas pelos estudantes em ensino clínico podem condicionar as suas aprendizagens e desenvolvimento pessoal e profissional, privilegiou-se a abordagem qualitativa de natureza descritiva e interpretativa ${ }^{[31,32,33]}$.

A recolha de dados foi efetuada recorrendo à aplicação da técnica de focus-group ${ }^{[34,35,36]}$ a sessenta e oito professores de treze Escolas Superiores de Enfermagem | Saúde de Portugal Continental, com responsabilidades a diferentes níveis do processo formativo quer teórico quer prático. Para o tratamento dos dados, aplicou-se a técnica de análise de conteúdo temática ${ }^{[1,37,38]}$, seguindo o percurso metodológico sugerido por Bardin ${ }^{[1]}$. Definiu-se uma matriz temática, construída na interação entre os elementos emergentes das narrativas dos sujei- 
lowed by a contextualization operation thereof within the topics appearing on the first thematic matrix.

Both the array of topics and the context changed during the procedure, interpellating each other and being interpellated in the light of research objectives to obtain a final matrix. Within each theme, the comparison of registration units was performed. We proceeded to regrouping the same by similarity or difference, obtaining subcategories and categories. To control the process, the data was checked to determine whether these were mutually exclusive, relevant, and covered the entire information collected, making adjustments when such was not the case. In a subsequent, more interpretative, step, we transformed the registration units into indicators.

Internal validity was obtained by the participants and external validity by experts from the fields of Nursing and Educational Sciences, which not only certified the stability of the categorical system which emerged, but also the explanation advanced for the phenomenon under study.

The protocol for ethical procedures was fully complied by providing detailed explanation of the objectives of the study to participants, obtaining their consent, as well as through the formal authorization of the Colleges leaders which hosted the fieldwork.

\section{Results}

From data collected a set of indicators emerged which resulted in six categories - the reality shock, interaction with the supervisor, related with training process itself, interaction with the teacher, interaction with patient / family, interaction with nursing staff - which in turn led to the theme "perceived difficulties / felt by students in clinical training", which we systematized in Table 1. Throughout the analysis, registration units are presented, in the words of the participants, to clarify / illustrate aspects considered relevant.

\section{Reality shock}

The theory-practice dichotomy emerges from the marked sense of perceived conceptual disarticulation between the school and the contexts, visible in the "routine way" that they organize care and the excessive focus on technical procedures (biomedical model).

"We teach a straight theory, explain the fundamentals of the interventions but then, during the internship, they let themselves loosing that culture and "it even looks tos e os temas identificados na literatura da especialidade. Seguidamente foi efetuada a descontextualização das unidades de análise, relativamente aos discursos iniciais, seguida de uma operação de contextualização das mesmas no interior dos temas que constavam na primeira matriz temática. Tanto a matriz de temas como a contextualização mudaram no decurso do processo, interpelando-se mutuamente e sendo interpeladas à luz dos objetivos da investigação até ser obtida uma matriz definitiva. No interior de cada tema foi efetuada a comparação das unidades de registo. Por semelhança ou diferença, procedemos ao reagrupamento das mesmas, obtendo subcategorias e categorias. Para controlo do processo verificou-se se estas eram mutuamente exclusivas, pertinentes e cobriam a totalidade da informação recolhida, fazendo reajustes quando tal não se verificava. Numa fase subsequente, mais interpretativa, transformámos as unidades de registo em indicadores. A validade interna foi obtida pelos participantes e a externa por peritos das áreas da Enfermagem e das Ciências da Educação, que não só certificaram a estabilidade do sistema categorial emergido, como também a explicação desenvolvida para o fenómeno em estudo.

Foi cumprido o protocolo de procedimentos éticos da investigação com a explicação detalhada dos objetivos do estudo aos participantes, da obtenção do seu consentimento, bem como através da autorização formal dos líderes das Escolas onde decorreu o trabalho de campo.

\section{Resultados}

Da análise dos dados recolhidos emergiram um conjunto de indicadores que deram lugar a seis principais categorias - choque da realidade, interação com o supervisor, o próprio processo formativo, interação com o professor, interação com o utente | família, interação com a equipa de enfermagem - que por sua vez originaram o tema "Dificuldades percebidas | sentidas pelos estudantes em ensino clínico" que sistematizamos seguidamente na Tabela 1. Ao longo da análise serão apresentadas unidades de registo, nas próprias palavras dos participantes, no sentido de clarificar | ilustrar aspetos considerados relevantes.

\section{Choque da realidade}

A dicotomia teoria-prática emerge do marcado sentimento de desarticulação conceptual percebido entre a escola e os contextos, visível na forma "rotineira" como estes organizam os cuidados e na excessiva focalização nos procedimentos técnicos (modelo biomédico).

\section{“(...)nós ensinamos a teoria, direitinha, explicamos os}


like they construct new theories", over those which we teach...” (FG5:10)

The confrontation with the complexity of reality stems from having to deal with the unexpected. In this context, prioritizing activities and making decisions "just in time", was described as potentially generating insecurity, confusion and anxiety for the student.

In situation, the complexity prevails: it is necessary to be constantly attentive to the needs of each patient and tailor care (..). On the other hand, it is required that the student can combine this with all the other things they have to do. It is very complicated, there are many requests and they get a little disoriented ... " (FG3: 31)

Associated with the listed adversities, the difficulty arises in mobilizing situated knowledge and therefore taking the initiative. The shortage of human resources in nursing due to the political and organizational instability of healthcare organizations is also an embarrassment, leading, not infrequently, to students who are prevented from having adequate training experiences to their level of development and / or achieve the defined objectives for the clinical training.

there is a lack of human resources ... (...) it is self-evident and turns out to have impacts on the normal development of the internships. Students go there, often without orientation (...) this ultimately compromises the learning and the achievement of the goals set for the internship (FG7:7)

The management of "professional feelings" during instances of suffering, death and confrontation with extreme situations, were a source of a real embarrassment.

"Another great difficulty I would point out, is the confrontation with human suffering, with death, realizing that he [student] or someone in his family may also be in that situation" (FG2:31)

During care, the contact with the patient's body seems to be also a factor generating discomfort, anxiety and insecurity, particularly if the body has hygiene deficits, wounds, severe bleeding, burns or deformities by accident or trauma.

Dealing with the patient's body, feeling the "meat", feeling whether it is cold, hot, wet or dry is complicated for them [students] ... So if there are wounds and the wounds are intensively bleeding or have a disgusting appearance and an active smell, in the first contacts, the students are unwilling and not even scientific curiosity makes them want to participate in the care of the patient ... “( FG7:21)

Associated with previous difficulties, students even feel fundamentos das intervenções mas, depois no estágio, eles deixam-se aculturar e "até parece que constroem novas teorias", sobre aquelas que lhes ensinámos..." (FG5:10)

O confronto com a complexidade do real decorre de ter que lidar com o imprevisto. Neste âmbito, priorizar as atividades e tomar decisões "just in time", é descrito como potencialmente gerador de insegurança, confusão e ansiedade para o estudante.

Em situação, a complexidade impera: é necessário estar permanentemente atento às necessidades de cada utente e adequar os cuidados (..). Por outro lado, é exigido que o estudante consiga conjugar isso com todas as outras coisas que tem que fazer. É muito complicado, são muitas solicitações... eles ficam um pouco desorientados..." (FG3:31)

Associada às adversidades enumeradas, emerge a dificuldade em proceder à mobilização situada dos conhecimentos adquiridos e consequentemente tomar a iniciativa.

A escassez de recursos humanos em enfermagem decorrente da instabilidade politico-organizativa das organizações de saúde, constitui também um constrangimento, conduzindo, não raramente, a que o estudante fique impedido de ter experiências formativas adequadas ao seu nível de desenvolvimento e $\mid$ ou atinja os objetivos definidos para o ensino clínico:

“(...) há falta de meios humanos... (...) isso é por demais evidente e acaba por ter repercussões no normal desenvolvimento dos estágios. Os estudantes andam lá, muitas vezes, sem orientação (...) isto acaba por comprometer a aprendizagem e o atingir dos objetivos definidos para o estágio" (FG7:7)

A gestão de "sentimentos profissionais" como o sofrimento, a morte e o confronto com situações limite, constituem um verdadeiro embaraço:

"Outra grande dificuldade que eu apontava é o confrontar-se com sofrimento humano, com a morte, perceber que ele [estudante] ou alguém da sua família, também pode estar nessa situação..." (FG2:31)

Durante a prestação de cuidados, o contacto com o corpo dos doentes, parece ser também um fator gerador de desconforto, ansiedade e insegurança, particularmente se esse corpo apresenta défices de higiene, feridas, hemorragias graves, queimaduras ou deformações por acidente ou traumatismo.

“(...) lidar com o corpo do doente, sentir a "carne", sentir se está fria, quente, seca ou húmida é complicado para eles [estudantes]... Então se tiver feridas e essas feridas forem muito sangrantes ou tiveram um aspeto repugnante e cheiro ativo, nos primeiros contactos, eles ficam indis- 
embarrassed by entering the patient's intimacy, whether physical or space / patient's environment.

\section{Interaction with the supervisor}

The negative relational-affective environment can, in itself, influence student performance, and ultimately determine his success or failure on the internship. Aspects such as unfamiliarity with the supervisor, the level of his demands, having several supervisors during the same clinical training and avoiding being questioned for fear of criticism, appear as impediments to the establishment of a positive affective-relational atmosphere.

They [students] start soon with fear: "Will it be an element of aid, or will be an element that intimidates me and affects my learning and the final grade of the internship ...?!” (FG2:19)

The unavailability / supervisor's lack of time, by accumulation of caring and supervision functions, is also cited as a constraint:

They [supervisors] have many tasks facing the ratios and end up not having psychological or time availability to respond to requests from students (FG4:10)

Consequently, the clinical training is often confined to observation or the student is left "to his fate", inhibiting the possibility of mutual exploitation of work situations and performance of apprenticeships in a reflective way. The lack of training in clinical supervision and the systematic use of supervision directive styles are also considered obstacles to effective and efficient supervision and establishment of an assertive relationship.

(...) Currently what we find is that many of the nurses who work in the supervision of students, have no preparation for it and don't have personal or professional availability to acquire the needed training ... “(FG7:3)

The personal characteristics of students such as shyness, inhibition, insecurity, excessive anxiety, immaturity and lack of interest are highlighted as a factor that can stimulate or, conversely, discourage the interaction between student - supervisor / multidisciplinary team / patient and family.

\section{Related with training process itself}

The difficulties inherent to the students themselves mostly have to do with the poor preparedness and "fears" perceived / felt during clinical teaching. The fear of failure, of not being able to fulfill expectations, and the evaluation emerge as impediments to the development of the student, either in personal or professionals terms. postos e nem a curiosidade cientifica os faz querer participar nos cuidados às mesmas..." (FG7:21)

Associada à dificuldade anterior, os estudantes sentem-se também embaraçados por entrar na intimidade do(s) utente(s), seja física ou o espaço $\mid$ ambiente do utente.

\section{Interação com o supervisor}

O ambiente afetivo relacional desfavorável pode, por si só, influenciar o desempenho do estudante e, no limite, determinar o seu sucesso ou insucesso em estágio. Aspetos como, o desconhecimento do supervisor; o grau de exigência deste; ter múltiplos supervisores durante o mesmo ensino clínico e evitar ser questionado por medo da crítica, emergem como impedimentos ao estabelecimento de uma atmosfera afetivo-relacional positiva:

"Eles [estudantes] começam logo por recear: "Será que vai ser um elemento de ajuda, ou vai ser um elemento que me intimida e que me prejudica na minha aprendizagem e na nota final de estágio?!...” (FG2:19)

A indisponibilidade | falta de tempo dos supervisores, por acumulação das funções cuidativa e supervisiva, é também apontada como um constrangimento:

Eles [supervisores] têm muitos afazeres face aos ratios $e$ acabam por não ter nem disponibilidade de tempo nem psicológica para responder às solicitações dos alunos, (FG4:10)

Consequentemente, não raras vezes, o ensino clínico confina-se à observação ou então o estudante é deixado "à sua sorte", inibindo-se a possibilidade de exploração mútua das situações de trabalho e de realizar aprendizagens por via reflexiva. A ausência de formação em supervisão clínica e o sistemático recurso a estilos supervisivos de tipo diretivo são também considerados obstáculos a uma supervisão eficaz e eficiente e ao estabelecimento de uma relação assertiva.

(...) atualmente o que nós verificamos é que muitos dos enfermeiros que colaboram na supervisão dos estudantes, não têm preparação para tal e também não têm disponibilidade nem pessoal nem profissional para adquirir formação...” (FG7:3)

Características pessoais do estudante como timidez, inibição, insegurança, ansiedade excessiva, imaturidade e desinteresse, são destacadas como fator que pode estimular ou, contrariamente, desencorajar a interação ente estudante - supervisor | equipa multidisciplinar | utentes e família.

\section{Relacionadas com o próprio processo formativo}

As dificuldades intrínsecas ao próprio estudante prendem-se essencialmente com a frágil preparação prévia e com “os medos" percebidos $\mid$ sentidos durante os ensinos clíni- 
(...) Often students have this problem, which is the fear of own clinical training, fear of the unknown, fear of failure, fear of being unable to perform to expectations. (...) These fears, if not controlled, eventually weigh a bit and hinder the learning process ... " (FG5:50)

With regard to curricular issues, teachers report that students complain of excessive academic work required during clinical teaching. They further refer that the student feels embarrassed when confronted with situations for which he had no previous theoretical preparation.

"(...) often, supervisors who are on the ground make it available for students to conduct experiments for which they are not theoretically prepared, and then they are shuffled and confused... " (FG8:37)

The curricular reorganization resulting from the Bologna Process and the successive reforms verified in nursing education are also perceived by the student as obstacles to the quality and results of learning in clinical training.

With regard to the organizational issues, the short duration and intensiveness of internships and the high number of students at the same time in the contexts, are factors considered inhibitors to student development in terms of instrumental, relational or systemic skills, as can be inferred from the following excerpts:

“(...) practice being the ideal place for experimentation, currently, due to the massiveness of students in the same contexts, it is impossible for them to experience on the various techniques of nursing ... On the other side, it is also impossible to respect the working patterns of each student, because as we know, the internships are short and students consume more time to develop their activities ... " (FG12:4)

\section{Interaction with the teacher}

Despite the desirable and necessary positive affectiverelational environment between student and teacher in clinical training, representations and previous experiences are indicated as constraints that can compromise the training process.

"Often, when the student has had any problem with the teacher during the theoretical education or does not like the teacher, feels fear in particular to talk to him about their doubts or about the inconsistencies observed between theory and practice ... " (FG8:33)

The spectrum of evaluation is always present "in the mind" of the student and the teacher is seen as "the one who gives the grade". This perception not only affects the student's spontaneity but also induces defensive behavior in the teacher's presence. cos. O medo de errar, de não ser capaz de corresponder às expectativas e da avaliação, emergem assim como impedimentos ao desenvolvimento do aluno, quer em termos pessoais quer profissionais:

(...) muitas vezes os estudantes têm muito esse problema, que é o medo do próprio ensino clínico, medo do desconhecido, medo de errar, medo de não serem capazes de ter um desempenho à altura das expectativas. (...) esses medos, quando não controlados, acabam por pesar um bocadinho e dificultam o processo de aprendizagem..." (FG5:50)

Relativamente às questões curriculares, os professores referem que os estudantes se queixam dos múltiplos e demasiados trabalhos académicos solicitados durante os ensinos clínicos. Referem ainda, que o estudante se sente constrangido, quando é confrontado com situações para as quais ainda não teve preparação teórica prévia:

“(...) muitas vezes, os orientadores que estão no terreno, colocam à disposição dos alunos a realização de experiências para as quais eles não estão preparados teoricamente, e depois, eles ficam baralhados e confusos..." (FG8:37)

Também a reorganização curricular decorrente do Processo Bolonha e as sucessivas reformas verificadas no ensino em enfermagem, são percebidas pelo estudante como obstáculos à qualidade e resultados das aprendizagens realizadas em ensino clínico.

No que respeita às questões organizativas, a curta duração dos estágios, a intensividade dos mesmos, o elevado número de estudantes em simultâneo nos contextos, são fatores considerados inibidores do desenvolvimento do estudante quer em termos de competências instrumentais, relacionais ou sistémicas, como se pode inferir dos seguintes excertos:

“(...), sendo a prática o lugar ideal para a experimentação, atualmente, face à massividade de alunos nos mesmos contextos, torna-se impossivel eles experimentarem-se nas diversas técnicas de enfermagem... Por outro, lado, é também impossível respeitar os ritmos de trabalho de cada aluno, pois como se sabe, os estágios são curtos e os alunos consomem mais tempo para desenvolverem as suas atividades..." (FG12:4)

\section{Interação com o professor}

Apesar do desejável e necessário ambiente afetivo-relacional positivo entre estudante e professor em ensino clínico, as representações e as experiências prévias são apontadas como constrangimentos capazes de comprometer o processo formativo:

"Muitas vezes, o aluno quando já teve algum problema com o professor durante o ensino teórico ou não gosta do 
"(...) They have fear of the evaluation and know that it is us who launch the grade... (...) they are dependent on an evaluation, a grade, have to try to show that they know, or answer what they think the evaluator wants to hear..."

\section{Interaction with the patient / family}

Although the students have had theoretical and practical-theoretical training in relational / communication areas, in clinical practice the fact is that the interaction with the patient / family, group or community is not confined to the application of "recipes" learned previously.

Theoretically, they say everything right, speak of the importance of helping relationship, have a data collection script, can establish a relationship because it is just necessary to follow the questions of the script ... but if they have a specific reason, spontaneously, they have difficulty in the initial approach to the patient or family ... " (FG10:11)

This dissonance is particularly evident in specific interactions developed in contexts such as Pediatrics or Community Health and also in complex clinical cases in which patients are under great physical, psychological or social weakness.

\section{Interaction with nursing staff}

The work contexts offer unique opportunities for learning, but there are situations in which the climate of the contexts is not always suitable to welcome and facilitate professional situations that promote students' personal and professional development.

"(...) Most of the complaints ... or rather, most of the students' difficulties do not have to do with the (...) multidisciplinary team, but with the nursing team and the way it interacts with the student ..." (FG1:64)

Exacerbating this perception,teachers report that the students feel and complain of the psychological pressure exerted by the nursing team during clinical teaching.

“(...) In some contexts, in internship meetings, the students complain about the" psychological pressure "exerted by the nursing team on them ... [The nursing staff] They are constantly putting them to the test! ..." (FG9:41) professor, sente receio do mesmo designadamente em falar com ele sobre as suas dúvidas ou sobre as incongruências que observa entre a teoria e a prática..." (FG8:33)

O espetro da avaliação está sempre presente "na cabeça" do estudante, sendo o professor visto como "aquele que atribui a nota". Tal perceção não só condiciona a espontaneidade do estudante como o induz a comportamentos defensivos aquando da presença do professor:

"(...)Eles têm receio da avaliação e sabem que somos nós quem lançamos a nota na pauta... (...) eles estão dependentes de uma avaliação, de uma nota, têm que tentar mostrar que sabem, ou então responderem aquilo que acham que o avaliador quer ouvir..." (FG11:11)

\section{Interação com o utente | família}

Apesar de na componente teórica o estudante ter formação teórica e teórico-prática na área relacional $\mid$ comunicacional, fato é que em contexto clínico, a interação com o utente | família, grupo ou comunidade não se confina à aplicação de "receitas" aprendidas previamente:

Teoricamente, dizem tudo direitinho, falam da importância da relação de ajuda, se têm um guião de colheita de dados, conseguem estabelecer a relação, pois basta seguir as questões do guião... mas se não tiverem uma razão específica, espontaneamente, eles têm muita dificuldade na abordagem inicial ao utente ou à família... " (FG10:11)

Esta dissonância é particularmente evidente nas interações desenvolvidas em contextos específicos como a Pediatria ou a Saúde Comunitária e, ainda, em casos clínicos complexos em que os utentes estejam sob grande fragilidade física, psicológica ou social.

\section{Interação com equipa de enfermagem}

Os contextos de trabalho oferecem oportunidades únicas de aprendizagem porém, situações há, em que o clima dos contextos nem sempre é propício ao acolhimento e à facilitação de situações profissionais promotoras do desenvolvimento profissional e pessoal do estudante:

“(...) grande parte das queixas... ou melhor, das dificuldades dos estudantes não têm a ver com a (...) equipa multidisciplinar, mas sim, com a equipa de enfermagem e com a forma como a mesma interage com o aluno..." (FG1:64)

A agudizar esta perceção os professores referem que o estudante sente e queixa-se da pressão psicológica exercida pelas equipas de enfermagem durante os ensinos clínicos:

“(...) em alguns contextos, eles, nas reuniões de estágio, queixam-se da "pressão psicológica" exercida pela equipa de enfermagem exerce sobre eles... [as equipas de enfermagem] Estão constantemente a colocá-los à prova!..." (FG9:41) 
Table 1/ Tabela 1. Theme Categorical Matrix "Difficulties perceived $\mid$ felt by the students according to teachers'

\section{Matriz Categorial do Tema "Dificuldades percebidas | sentidas pelos estudantes segundo os professores"}

Tema: Dificuldades percebidas | sentidas pelos estudantes segundo os professores

Theme: Difficulties perceived $\mid$ felt by the students according to teachers

\begin{tabular}{l}
$\begin{array}{r}\text { Categoria } \\
\text { Categories }\end{array}$ \\
\hline
\end{tabular}

Subcategorias

Subcategories

Dicotomia teoria - prática

Theory - practice dichotomy

Confronto com a complexidade do real

Confrontation with the complexity of reality

1. The reality shock

Instabilidade político-organizativa das organizações

de saúde

Political and organizational instability of health

organizations

Gestão de "sentimentos profissionais"

Management "Professional Feelings"

Ambiente afetivo-relacional desfavorável

Adverse affective and relational environment

Impreparação do supervisor para a função

supervisiva

Supervisors` unpreparedness for supervision

2. Interação com supervisor function

2 Interaction with the supervisor

Estilos de supervisão

Supervision styles

Indisponibilidade do supervisor para a função

Supervisors' unavailability for the function

Características pessoais do estudante

Personal student characteristics

Aspetos intrínsecos ao próprio estudante

3. O próprio processo formativo

Intrinsic aspects of student himself

3. The training process itself

Aspetos curriculares e organizativos

Curricular and organizational aspects

Ambiente afetivo-relacional desfavorável

4. Interação com o professor

Adverse affective and relational environment

4. Interaction with the teacher

Papel do professor como avaliador

Teachers` role as evaluator

5. Interação com o utente | família

5. interaction with patient $\mid$ family

6. Interação com a equipa de

enfermagem

6. Interaction with nursing staff

\section{Discussion}

In category Reality shock ${ }^{[20.46]}$, the participants stress the existing conceptual and ideological gap between school education - Ideal Nursing - and the exercise of clinical practice - Real Nursing ${ }^{[5]}$. This disarticulation seems to be a fundamental condition for the establish-

\section{Discussão}

Na categoria choque da realidade ${ }^{[18,40]}$, os participantes colocam em evidência a clivagem conceptual e ideológica existente entre a formação escolar - Enfermagem Ideal - e o exercício da prática clínica - Enfermagem Real $-{ }^{[5]}$. Demonstram ainda, que esta desarticulação, 
ment of a distancing relationship between the "world of theory" and the delegitimization of their own educational institution ${ }^{[3,18,47]}$. The confrontation with the complexity of contexts and work situations and the political and organizational instability currently experienced in health organizations are referred as potentially generators of anxiety, dissatisfaction, and insecurity, and if not well-managed can compromise the socialization and the identity construction of the future professional. These findings mirror those in other investigations in the area of initial nursing training. ${ }^{[2,3,18,25]}$

In the teachers' words, the practice is also a strong emotional workspace-time for students, in which they are confronted with and learn to manage "professional feelings" related to pain, suffering and death. Considering the "dangers" or negative effects that this experience may have, our results align with those other authors who advocate they are redoubling efforts to ensure the achievement of agreed objectives for clinical education but, above all, to block undesired effects ${ }^{[48,49]}$.

In the category interaction with the supervisor, as in other studies ${ }^{[2,3,6,7,9,10,14,16,25,27,29,30,50,51,52,53]}$, the existence of dissonance between the desired interaction between supervisor and student, and the one that actually occurs on the ground, is demonstrated. Generally, we can say that these dysfunctions sometimes relate to variables more related to the supervisor figure, sometimes with the student characteristics.

With regard to supervisors, aspects such as the work overload and the consequent unavailability, the lack of training in clinical supervision and the style of supervision practiced, essentially directive ${ }^{[54]}$, determine the type of relationship established

In this regard, Simões et al. ${ }^{[15]}$ and Simões ${ }^{[55]}$ note that work overload, authoritarianism and lack of training lead to a deficient supervision, with the result that is the supervisors find that it is easier to do (themselves) than help and guide the students to do necessary tasks. Abreu ${ }^{[7]}$ suggests that supervisors should ideally not be counted towards the group of nurses who develop clinical practice.

In the case of students, the personal characteristics identified by teachers - shyness, inhibition, insecurity, excessive anxiety, immaturity and lack of interest, are mentioned in the literature as favorable to the development of disruptive provisions compromising of everyday interpersonal relationships, the evaluation process, and, ultimately, the student's own academic success $[2,3,25,27,29]$.

In category difficulties related with training process itself, the intrinsic aspects to the student, in particular the "fragile preparedness" and "fears", gain special parece ser condição determinante para o estabelecimento de uma relação de distanciamento face ao "mundo da teoria" e de deslegitimação da própria instituição escolar [3,16,41]. O confronto com a complexidade dos contextos e das situações de trabalho e a instabilidade político-organizativa vivida atualmente nas organizações de saúde, são também reiteradas como potencialmente geradores de ansiedade, insatisfação e insegurança que, quando não bem geridas, podem comprometer a socialização e construção identitária do futuro profissional. Tais achados encontram espelho em outras investigações na área da formação inicial em enfermagem ${ }^{[2,3,17,22]}$. No dizer dos professores, a prática constitui também um espaço-tempo de forte trabalho emocional para os estudantes, no qual estes são confrontados e aprendem a gerir "sentimentos profissionais" relacionados com a dor, o sofrimento e a morte. Considerando os "perigos" ou efeitos negativos que tal experiência poderá acarretar, alinhamos os nossos resultados com os de outros autores que defendem que sejam redobrados esforços no sentido de assegurar a concretização dos objetivos estipulados para o ensino clínico mas, sobretudo, se procure o evitamento de efeitos menos desejados ${ }^{[42,43]}$.

Na categoria interação com o supervisor, à semelhança de outros estudos $[2,3,6,7,9,10,13,15,22,23,24,26,44,45,47]$, é evidenciada a existência de dissonâncias entre a interação desejada entre supervisor e estudante, e aquela que efetivamente ocorre no terreno. Genericamente, podemos afirmar que essas disfuncionalidades ora se prendem com variáveis mais ligadas à figura do supervisor, ora com as características do estudante. No que respeita aos supervisores, aspetos como a sobrecarga de trabalho e consequente indisponibilidade; a ausência de formação em supervisão clínica e o estilo de supervisão praticado, essencialmente diretivo ${ }^{[46]}$, condicionam o tipo de relação estabelecida. A este propósito, Simões et al. ${ }^{[14]}$ e Simões ${ }^{[48]}$ referem que a sobrecarga de trabalho, o autoritarismo e a falta de formação conduzem a uma supervisão deficitária, levando a que seja mais fácil fazer do que ajudar e o orientar a fazer. Abreu ${ }^{[7]}$ sugere que os supervisores idealmente não devem ser contabilizados para o grupo de enfermeiros que desenvolvem práticas clínicas. No caso dos estudantes, as características pessoais identificadas pelos professores - timidez, inibição, insegurança, ansiedade excessiva, imaturidade e desinteresse, são também apontadas na literatura como propícias ao desenvolvimento de disposições disruptivas comprometedoras das relações interpessoais quotidianas, do processo avaliativo e, no limite, do próprio sucesso académico do estudante ${ }^{[2,3,22,23,25]}$.

$\mathrm{Na}$ categoria dificuldades relacionadas com o próprio processo formativo, os aspetos intrínsecos ao estudante, 
emphasis, bringing out insecurity, stress and anxiety experienced during the internship. These findings are consistent with other studies ${ }^{[2,3]}$, whose results show that the student is afraid of the unknown, the contexts, the people, of making mistakes and causing damage to the patient, and not becoming a good professional. With regard to curricular issues, the demand of multiple academic tasks by teachers, successive reforms in nursing education, and curricular reorganization resulting from the Bologna Process, are identified as potentially constrictive factors of student learning. For the two latter aspects, some authors share the opinion that the multiple reforms have gradually removed teachers of clinical practice ${ }^{[14,16]}$, suggesting that alternatives should be considered for the enhancement of the teaching role in clinical teaching ${ }^{[4]}$.

Also the organizational issues of clinical teaching might influence the process of "becoming a nurse." Indeed, on the one hand, the internship can provide very rich experience, on the other hand, the short duration, high intensity and the number of students simultaneously in clinical settings may prevent the accomplishment of the defined objectives to the extent that the student consumes considerable time to become familiar with the context, resources, people, tasks and "routines" that are part of the institutional every day.

In the category interaction with the teacher, the students' representations about the teacher, the relational experience taken during the theoretical period, and the increased perception of "teacher as evaluator" stands out in the participants' discourse. In a study on the evaluation of learning in clinical education, Carvalho ${ }^{[56]}$ justifies this perception stating that " $(. .$.$) the students$ feel that teachers assess more by the mistakes that students make than for the good things they do" (p. 301). In the category interaction with the patient/family, similar to the results obtained in other studies ${ }^{[2,3,18,57]}$, the difficulty of the student effectively communicate with the patient / family emerges from teachers' speeches as a limitation to the establishment of close relations, complementarily and partnership.

Simões et al. ${ }^{[15]}$ state that the students engage emotionally with patients because of their insecurity and inexperience, with such involvement having negative repercussions for the establishment of a therapeutic relationship and help.

In the category interaction with the nursing staff, participants emphasized the difficulties of integration / acceptance of the student within the nursing team and also the psychological pressure exerted by this, by the systematic interference in their activities, inhibiting or even discrediting their performance.

According to Sierra ${ }^{[18]}$, the identity construction of the nomeadamente, a "frágil preparação prévia" e os "medos" ganham especial relevo colocando em evidência a insegurança, stresse e ansiedade vividos durante o estágio. Estes achados estão em consonância com outros estudos [2,3], cujos resultados revelam que o estudante sente medo do desconhecido, dos contextos, das pessoas, de errar e causar dano ao utente e de não vir a ser um bom profissional. Relativamente às questões curriculares, a solicitação de múltiplos trabalhos académicos pelos professores; as sucessivas reformas no ensino de enfermagem e a reorganização curricular decorrente do Processo Bolonha, são apontadas como fatores potencialmente constritivos da aprendizagem do estudante. Relativamente aos dois últimos aspetos, alguns autores são unanimes em considerar que as múltiplas reformas têm afastado gradualmente os docentes da prática clínica ${ }^{[14,16]}$, sugerindo que devem ser consideradas alternativas para a valorização do papel docente em ensino clínico ${ }^{[4]}$. Também as questões organizativas dos ensinos clínicos podem condicionar o processo de "tornar-se enfermeiro". Com efeito, se por um lado, os estágios podem proporcionar experiências riquíssimas, por outro lado, a sua curta duração, intensividade e o elevado número de estudantes em simultâneo nos contextos clínicos podem inviabilizar o atingir dos objetivos definidos, na medida em que o estudante consome um tempo considerável a familiarizar-se com o contexto, os recursos, as pessoas, as tarefas e as "rotinas" que fazem parte do quotidiano institucional.

$\mathrm{Na}$ categoria interação com o professor, as representações do estudante acerca do professor; a experiência relacional tida durante o período teórico e a vincada perceção do "professor enquanto avaliador" marcam o discurso dos participantes. Num estudo sobre a avaliação da aprendizagem em ensino clínico, Carvalho ${ }^{[48]}$, justifica tal perceção referindo que “(...) os alunos acham que os professores avaliam mais pelos erros que os alunos cometem do que pelas coisas boas que fazem" (p.301).

Na categoria interação com o utente | família, à semelhança dos resultados obtidos em outras investigações [2,3,16], transparece dos discursos dos professores, como limitação ao estabelecimento de relação de proximidade, complementaridade e parceria, a dificuldade de o aluno comunicar eficazmente com o utente $\mid$ família. Simões et al. ${ }^{[14]}$ afirmam que os alunos, pela sua insegurança e inexperiência, envolvem-se emocionalmente com os doentes, originando esse envolvimento repercussões negativas para o estabelecimento de uma relação terapêutica e de ajuda.

$\mathrm{Na}$ categoria interação com a equipa de enfermagem, os participantes enfatizam as dificuldades de integração | aceitação do estudante no seio da equipa de 
student can be strongly influenced in the face of such attitudes, since the sense of inclusion and belonging are prerequisites.

\section{Conclusion}

The practical component is indispensable in the clinical training process of students in initial nursing training. Currently, however, this practice is imbued with tremendous complexity and a degree of growing demand, and there is evidence that recognizes the lack of congruence between their purposes and the actual conditions in which it occurs. Such inconsistency is corroborated in the categories of difficulties experienced by students, according to teachers: the reality shock, interaction with the supervisor, related with training process itself, interaction with the teacher, interaction with patient / family, and interaction with nursing staff. Gathering the best evidence for understanding the place of practice in the initial training of nurses, an added value for the development of this training component was revealed. In this context, the need stands out to develop studies whose objectives are the contexts, actors and processes that help responsible entities and actors directly involved in the (re)conceptualization and organization of clinical teaching, clarifying their purposes and goals beyond speech and regulatory frameworks.

\section{Conflict of interests}

The author declares that there are no financial or personal relationships that could be viewed as potential conflict of interest. enfermagem e também a pressão psicológica exercida por esta, pela sistemática interferência as suas atividades, inibindo ou mesmo desacreditando o seu desempenho. De acordo com Serra ${ }^{[16]}$, um aspeto que pode ser fortemente condicionado face a tais posturas é a construção identitária do estudante, uma vez que o sentido de inclusão e de pertença são condições indispensáveis à mesma.

\section{Conclusão}

A componente prática é indispensável no processo de formação clínica dos estudantes na formação inicial em enfermagem. Porém, atualmente, esta prática está imbuída de uma enorme complexidade e de um grau de exigência crescente, existindo evidências que reconhecem a falta de congruência entre seus os propósitos e as condições concretas em que a mesma ocorre. Tal inconsistência é corroborada nas categorias de dificuldades sentidas pelos estudantes, segundo os docentes: choque da realidade, interação com o supervisor, o próprio processo formativo, interação com o professor, interação com o utente | família, interação com a equipa de enfermagem. Reunir a melhor evidência para compreender o lugar da prática na formação inicial de enfermeiros, revela-se assim, uma mais-valia para o desenvolvimento desta componente formativa. Neste âmbito, sobressai a necessidade de serem desenvolvidos estudos cujo objeto sejam os contextos, os atores e os processos, que auxiliem as entidades responsáveis e atores diretamente implicados à (re)conceptualização e organização dos ensinos clínicos, clarificando as suas finalidades e objetivos para lá do discurso e do quadro normativo.

\section{Conflitos de Interesse}

$\mathrm{O}$ autor declara que não existem relações financeiras ou pessoais que pudessem ser vistas como potenciais conflitos de interesse. 


\section{References/ Referências}

[1] Bardin L. análise de conteúdo. Lisboa: Edições 70, 2009.

[2] Rua M. De aluno a enfermeiro. Desenvolvimento de competências em contexto clínico. Loures: Lusociência, 2011.

[3] Fernandes O. Entre a teoria e a experiência. Desenvolvimento de competências de enfermagem no ensino clínico no hospital no curso de licenciatura. Loures: Lusociência, 2006.

[4] Serra M. Supervisão pedagógica de estudantes de enfermagem realizada por enfermeiros dos contextos de prática clínica a perspetiva dos atores. In: Rodrigues, MA. et al. Processos de formação na e para a prática de cuidados. Loures: Lusociência, 2007.

[5] Silva D, Silva E. O ensino clínico na formação em enfermagem. Millenium 2004, Mar $n^{\circ}$ 30. In: URL: http://www.ipv.pt/millenium/Millenium30/8.pdf

[6] Abreu W. Identidade, formação e trabalho. Das culturas locais às estratégias identitárias dos enfermeiros. Coimbra: Formasau, 2001.

[7] Abreu W. Formação e Aprendizagem em contexto clínico. Fundamentos, teorias e considerações didáticas. Coimbra: Formasau, 2007.

[8] D'Espiney L. Formação inicial | formação contínua de enfermeiros: uma experiência de articulação em contexto de trabalho. In: Canário, R. Formação e situações de trabalho. Porto: Porto Editora, 1997.p.169-188.

[9] Carvalhal R. Parcerias na formação. Papel dos orientadores clínicos. Lisboa: Lusociência, 2003.

[10] Longarito S. O ensino clínico: A importância da orientação e a construção do saber profissional. Sinais vitais $2002, n^{\circ} 5,26-33$.

[11] Franco J. Orientação de alunos em ensino clínico de enfermagem: problemáticas específicas e perspetivas de atuação. Investigação em Enfermagem 2000, nº 1, Fevereiro, 32-50.

[12] Amendoeira J. A Formação em enfermagem. Que conhecimento? Que contextos? Um estudo etno-sociológico. Tese de Mestrado. Lisboa: Faculdade de Ciências Sociais e Humanas, 1999.

[13] Cunha et. al. Atitudes do enfermeiro em contexto de ensino clínico: uma revisão de literatura. Millenium 2010, Jun $\mathrm{n}^{\circ}$ 38. In: URL: http://www.ipv.pt/millenium/Millenium38/ default.htm

[14] Simões J, Alarcão I, Costa N. Supervisão em ensino clínico de enfermagem: a perspetiva dos enfermeiros cooperantes. Referência 2008, Jun II ${ }^{\mathrm{a}}$ Série, $\mathrm{n}^{\mathrm{o}} 6$, 91108 In: URL: http://www.index-f.com/ referencia/2008pdf/0691108.pdf

[15] Dixe MA. Opinião dos estudantes de enfermagem sobre a orientação em parceria (enfermeiros orientadores e docentes) dos ensinos clínicos. Enfermagem 2007, Jun-Dez, n ${ }^{\circ}$ 47/48 ( $2^{\mathrm{a}}$ Série), 70-74

[16] Serra M. Aprender a ser enfermeiro. A construção identitária profissional por estudantes de enfermagem. Tese de Doutoramento. Lisboa: Instituto de Educação, 2011.
[17] Amendoeira J. Uma biografia partilhada da enfermagem. A segunda metade do século XX. Coimbra: Formasau, 2006.

[18] Mestrinho MG. Choque da realidade dos enfermeiros no início da carreira. Tese de Mestrado. Lisboa: Faculdade de Psicologia e Ciências da Educação, 1997.

[19] Gonçalves C. Supervisão Clínica de enfermagem: necessidades de formação dos docentes supervisores. Tese de Mestrado. Lisboa: Instituto de Educação, 2004.

[20] Gonçalves C. Conhecimento profissional e profissionalidade docente em enfermagem. Contributo do pensamento docente. Tese de Doutoramento. Lisboa: Instituto de Educação, 2012.

[21] Mestrinho MG. Profissionalismo e competências dos professores de enfermagem. Tese de Doutoramento. Lisboa: Instituto de Educação, 2011.

[22] Martins C. Competências dos supervisores de ensino clínico: representações de alunos de enfermagem. Tese de Mestrado. Faculdade de Psicologia e Ciências da Educação, 2009.

[23] Longo J. Supervisão clínica em enfermagem. Contributo para o estudo das necessidades de formação dos supervisores de ensino clínico. Tese de Mestrado. Faculdade de Psicologia e Ciências da Educação, 2005.

[24] Fonseca MJ. Supervisão em ensinos clínicos de enfermagem - perspetiva do docente. Tese de Mestrado. Universidade de Aveiro, 2004.

[25] Simões J. Supervisão em ensino clínico de enfermagem. A perspetiva dos enfermeiros cooperantes. Universidade de Aveiro, 2004.

[26] Belo A. Supervisão em ensino clínico de enfermagem. Perspetiva do aluno. Universidade de Aveiro, 2003.

[27] Carvalho A. O ensino clínico de enfermagem. Enfermagem 2006, n $42 / 43$ ( $2^{\mathrm{a}}$ Série), 11-16.

[28] Mestrinho MG. Formação e prática de enfermagem: o estado das parcerias em contextos formativos. In: AFIRSE Portuguesa, Regulação da Educação e economia: organização, financiamento e gestão. Lisboa: Faculdade de Psicologia e Ciências da Educação, 2004.p 310-324

[29] Mestrinho, MG. Parcerias na formação inicial de enfermeiros. In: Gomes, I. (org.). Parceria e cuidado de enfermagem - uma questão de cidadania. Coimbra: Formasau, 2007. p. 203-248.

[30] Matos E. A colaboração escola-serviços. Nursing 1997. Ano 10, n. ${ }^{\circ}$ 114. p. 31-34.

[31] Bogdan R, Biklen S. Investigação qualitativa em educação. Porto: Porto Editora, 1994.

[32] Denzin K, Lincoln Y. Handbook of qualitative research. Netbury park: Sage, 1994.

[33] Streubert H, Carpenter D. Qualitative research in nursing: Advancing the humanistic imperative (3rd ed.). Philadelphia: Lippincott Williams \& Wilkins, 2002.
[34] Longo J. Fernandes MJ. Focus group e processo ensino-aprendizagem em enfermagem: uma revisão sistemática da literatura. Biomedical and Biopharmaceutical Research 2014, 11 (1) 11-21.

[35] Krueger RA. Focus Groups: A Practical Guide for Applied Research. London: Sage Publications; 1994.

[36] Morgan D. Focus group as qualitative research $2^{\mathrm{a}}$ ed. Massachusetts: Sage; 1996.

[37] Estrela A. Teoria e prática de observação de classes: uma estratégia de formação de professores, $4^{\mathrm{a}}$ Ed. Porto: Porto Editora, 1994

[38] Ghiglione R, Matalon B. O inquérito. Oeiras: Celta Editora, 1992.

[39] Rodrigues MA. Metodologias de análise de necessidades de formação na formação contínua de professores: contributos para o seu estudo. Tese de Doutoramento. Lisboa: Faculdade de Psicologia e Ciências da Educação, 1999.

[40] Kramer M. Role conceptions of baccalaureate nurses and success in hospital nursing Nursing Research 1970, 19 (5), 428-439.

[41] Canário R. Aprendizagens e quotidianos profissionais. In: In: Rodrigues, MA. et al Processos de formação na e para a prática de cuidados. Loures: Lusociência, 2007.

[42] Caires S. Vivências e percepcões do estágio no ensino superior. Braga: Universidade do Minho, 2001.

[43] Caires S, Almeida L. Estágios curriculares: avaliação das vivências e percepções na transição do meio académico para o mundo do trabalho. Psicologia: teoria, investigação e prática 1998, 3(1), 83-96

[44] Araújo et al. Supervisão em contexto clínico: o testemunho dos estudantes sobre o(s) modelo(s) vigente(s). Revista de Formación e Innovación Educativa Universitaria 2012. Vol. 5, No 2, 112- 121

[45] Silva R, Pires R, Vilela C. Supervisão de estudantes de enfermagem em ensino clínicoRevisão sistemática de literatura. Referência 2011, Mar III ${ }^{a}$ Série, nº3, 113-122 In: URL: http://www.scielo.mec.pt/pdf/ref/vserIIIn3/ serIIIn3a12.pdf

[46] Glickman C, Gordon S, Ross-Gordon R. Supervision and instructional leadership - a developmental approach. $6^{\mathrm{a}}$ Ed. Fortworth: Harcourt Brace College Publishers, 2004.

[47] Simões, J. Supervisão em ensino clínico de enfermagem: três olhares cruzados. Revista Investigação em Enfermagem 2006. Ago $\mathrm{n}^{\circ} 14,3-15$.

[48] Carvalho AL. Avaliação da aprendizagem em ensino clínico no curso de licenciatura em enfermagem. Lisboa: Instituto Piaget, 2004 